\title{
HUBUNGAN FAKTOR - FAKTOR YANG MEMPENGARUHI PHLEBITIS TERHADAP TERJADINYA PHLEBITIS
}

\author{
Oleh; \\ Erika Lubis $^{1)}$, Widiastuti ${ }^{2)}$ \\ 1) Program Studi Ilmu Keperawatan STIKes Binawan, Email: erika@ binawan-ihs.ac.id \\ 2) Program Studi Ilmu Keperawatan STIKes Binawan, Email: erika@ binawan-ihs.ac.id
}

\begin{abstract}
ABSTRAK
Latar Belakang: Pemasangan infus merupakan prosedur invasif dan merupakan tindakan yang paling sering dilakukan di rumah sakit. Pemasangan terapi cairan intravena perlu diperhatikan lokasi penusukan vena, kondisi pasien antara lain: usia, riwayat penusukan vena sebelumnya, durasi pemasangan, lama pemasangan infus dan beberapa faktor lainnya untuk mencegah timbulnya komplikasi. Salah satu komplikasi terapi intravena yang sering terjadi adalah phlebitis. Hal ini dapat menyebabkan kerusakan permanen pada vena dan meningkatkan lama waktu perawatan. Tujuan penelitian ini adalah untuk mengetahui hubungan faktor- faktor yang dapat mempengaruhi phlebitis terhadap terjadinya phlebitis pada pasien di Ruang Anggrek RSUD Tarakan Jakarta Pusat.
\end{abstract}

Metode: Penelitian ini menggunakan desain penelitian Deskriptif Korelatif. Sampel penelitian ini sebanyak 57 orang.

Hasil: Penelitian menunjukan terdapat hubungan antara usia terhadap kejadian phlebitis ( $p$ value 0,016), tidak terdapat hubungan antara jenis kelamin terhadap kejadian phlebitis ( $p$ value 0,193$)$, terdapat hubungan antara lokasi pemasangan infus terhadap kejadian phlebitis ( $p$-value 0,007), tidak terdapat hubungan antara jenis balutan infus terhadap kejadian phlebitis ( $p$-value 0,702), terdapat hubungan antara penyakit penyerta terhadap kejadian phlebitis ( $p$-value 0,018), terdapat hubungan antara jenis cairan infus terhadap kejadian phlebitis ( $p$-value 0,049), terdapat hubungan antara lama terpasang infus terhadap kejadian phlebitis (p-value 0,014).

Pembahasan: Melakukan sosialisasi kepada seluruh perawat dalam melakukan penilaian Visual Infusion Phlebitis Score (VIP) sehingga mampu menentukan intervensi yang dilakukan untuk mencegah plebitis di rumah sakit. Untuk penelitian selanjutnya dapat mencari faktor lain yang menyebabkan plebitis dan melakukan komparasi standar penilaian plebitis dari Kemenkesh dan Joint Commission International (JCI) yang lebih mudah efektif digunakan oleh perawat dalam mencegah kejadian plebitis.

Kata kunci: Usia, Jenis Kelamin, Lokasi Pemasangan Infus, Jenis Balutan Infus, Penyakit Penyerta, Jenis Cairan Infus, Lama Terpasang Infus, Phlebitis. 


\title{
THE CORRELATION OF FACTORS AFFECTING PHLEBITIS ON OCCURRENCE OF PHLEBITIS
}

\author{
By; \\ Erika Lubis $^{1)}$, Widiastuti ${ }^{2)}$ \\ 1) Nursing Studi Program of STIKES Binawan, Email: erika@binawan-ihs.ac.id \\ 2) Nursing Studi Program of STIKES Binawan, Email: erika@binawan-ihs.ac.id
}

\begin{abstract}
Introduction: Insertition of an IV is an invasive procedure and the most frequently performed procedure in hospital. Administration of intravenous fluid therapy should be noted the location of venous puncture, patient condition include: age, previous venous pricking history, duration of installation, duration of infusion and several other factors to prevent the occurrence of complications. One of the most frequent complications of intravenous therapy is phlebitis. This can cause permanent damage to the veins and increase the duration of treatment. The purpose of this study is to determine the relationship of factors that can affect phlebitis on the occurrence of phlebitis in patients in Orchid Room Tarakan Hospital Jakarta Central.

Methods: This research uses descriptive correlative research design. The sample of this research is 57 people.

Results: The results showed that there was a correlation between age to phlebitis occurrence (p-value 0.016), there was no relationship between sexes on phlebitis (p-value 0.193), there was correlation between infusion location to phlebitis ( $p$-value 0,007) (P-value 0,018), there is correlation between infusion fluid type to phlebitis occurrence (p-value 0,049), there is relationship between type of infusion bandage to phlebitis incidence ( $p$-value 0,702) Long attached infusion to phlebitis incidence (p-value 0.014).

Discussion: Conducting socialization to nurses in Visual Infusion Phlebitis Score (VIP) assessment so as to determine interventions to prevent phlebitis in the hospital. For further research can look for other factors that cause phlebitis and comparative standarts of phlebitis assessment of Kemenkesh and Join Commission International (JCI) are more easily and effectively used by nurses in preventing incident phlebitis.
\end{abstract}

Keywords: Age, Sex, Infusion Site Location, Type of Infusion Dressing, Type of Infusion Dressing, Comorbidities, Type of Intravenous Fluids, Duration of Infusion, Phlebitis. 


\section{PENDAHULUAN}

Pemasangan infus merupakan prosedur invasif dan merupakan tindakan yang paling sering dilakukan di rumah sakit. Pemasangan infus adalah terapi cairan intravena yang merupakan metode efisien dan efektif memberikan cairan secara langsung ke kompartemen cairan intravaskular dan menggantikan kehilangan elektrolit (Kozier, et al. 2010).

Pemasangan terapi cairan intravena perlu diperhatikan lokasi penusukan vena, kondisi pasien antara lain: usia, riwayat penusukan vena sebelumnya, pada saat pemasangan infus; durasi pemasangan untuk mencegah cedera atau nyeri yang menimbulkan pasien ketakutan yang lebih besar ketika melakukan pemberian cairan intravena.

Lama pemasangan terapi cairan intravena yang efektif berdasarkan rekomendasi dari The Infusion Nursing Standards Of Practice dapat diperhatikan selama 72- 96 jam setelah pemasangan (INS. 2011).

Setiap pemasangan infus tidak selalu dapat bertahan sesuai dengan waktu yang ditentukan. Hal ini disebabkan karena adanya komplikasi utama terapi intravena diantaranya, infiltrasi, phlebitis, beban cairan berlebih, perdarahan dan infeksi. Phlebitis adalah keadaan inflamasi pada vena yang terjadi akibat beberapa faktor resiko terjadinya phlebitis diantaranya: materi kanula, iritasi kimia yang berasal dari substansi tambahan dan obat- obatan yang diberikan secara intravena (misalnya antibiotik) dan posisi anatomis kanula (Potter \& Perry. 2010).

Manifestasi klinis pada phlebitis yang sering terjadi dalam ruang perawatan adalah kemerahan disertai nyeri pada area pemasangan infus dan sampai terjadi bengkak. Phlebitis dapat menjadi bahaya, karena darah (thrombophlebitis) dapat terbentuk dan menyebabkan emboli. Hal ini dapat menyebabkan kerusakan permanen pada vena dan meningkatkan lama waktu perawatan (Potter \& Perry. 2010).

Phlebitis dapat menyebabkan thrombus yang selanjutnya menjadi thrombophlebitis. Apabila thrombus terlepas dan diangkut ke aliran darah kemudian masuk jantung maka dapat menimbulkan seperti katup bola yang menyumbat atrio ventikular secara mendadak dan menimbulkan kematian. Hal ini menjadikan phlebitis sebagai salah satu permasalahan yang penting untuk dibahas dan selain itu juga phlebitis juga sering ditemukan dalam proses keperawatan (Setio, H. Rohani. 2010)

Data statistik angka kejadian HAIs menurut Center For Disease Control and Prevention (CDC) yakni, menunjukkan data dari 183 rumah sakit di Amerika pada tahun 2011 memperkirakan terjadi 721, 
800 kasus infeksi yang diderita oleh 648, 000 pasien, sejumlah 75,000 pasien meninggal pada saat perawatan akibat HAIs (Uliyaden, 2014). Menurut Depkes RI (2006) jumlah kejadian infeksi nosokomial berupa phlebitis di Indonesia sebanyak $17,11 \%$.

Hasil studi pendahuluan di RSUD Tarakan melalui observasi yang dilakukan peneliti dibantu oleh petugas Infection Prevention and Control Nurse (IPCN) dari tanggal 1 Januari sampai dengan Juli 2016 di ruang perawatan Anggrek di temukan kejadian phlebitis dari pasien yang terpasang infus terdapat data bulan Januari 1 pasien phlebitis $(0,9 \%)$ dari 105 pasien, bulan Februari tidak ada kasus phlebitis dari 72 pasien, bulan Maret 1 pasien phlebitis $(1,1 \%)$ dari 86 pasien, bulan April dari 107 pasien, bulan Mei dari 112 pasien, bulan Juni dari 108 pasien dan bulan Juli dari 95 pasien tidak ditemukan kasus phlebitis $(0 \%)$.

Berdasarkan fenomena di Rumah Sakit RSUD Tarakan Ruang Rawat Anggrek bahwa pasien yang terpasang infus ratarata dipasang di area pergelangan tangan dari ruang IGD alasannya karena kondisi butuh penanganan cepat akses intravena yang mudah dilihat dan lebih besar oleh perawat. Pasien yang sudah terpasang infus 48- 72 jam tidak mau dipasang baru kateter infusnya sebelum terjadi kemerahan, nyeri atau bengkak alasannya

karena sakit saat pemasangan dan area pemasangan masih bisa dipertahankan serta belum memahami tentang resiko dari pemasangan infus. Belum banyak perawat diruang rawat Anggrek yang mengetahui bahwa mengukur skala phlebitis dengan Visual Infusion Phlebitis Score (VIP).

Melihat kejadian yang terjadi menurut data dan bahaya akibat phlebitis bahwa peran perawat sangat penting dalam mencegah terjadinya phlebitis, diharapkan perawat bekerja sesuai Standar Operasional Prosedur dan memperhatikan pasien yang terpasang infus dalam hal pemasangan dan perawatan infus untuk mengurangi angka kejadian phlebitis.

\section{BAHAN DAN METODE}

Penelitian ini menggunakan desain penelitian Deskriptif Korelatif. Sampel penelitian ini sebanyak 57 orang dari jumlah populasi sebanyak 110 orang. Tujuan dalam penelitian ini adalah untuk mengetahui adakah hubungan faktorfaktor yang dapat mempengaruhi phlebitis terhadap terjadinya phlebitis pada pasien di Ruang Anggrek RSUD Tarakan Jakarta Pusat 
HASIL

\section{Analisis Univariat}

Tabel 1. Distribusi Usia Responden

\begin{tabular}{lll}
\hline Usia & $\mathrm{f}$ & $\%$ \\
\hline 20-40 tahun & 9 & 15.8 \\
41-65 tahun & 34 & 59.6 \\
>65 tahun & 14 & 24.6 \\
Total & $\mathbf{5 7}$ & $\mathbf{1 0 0 . 0}$ \\
\hline
\end{tabular}

Tabel 2. Distribusi Jenis Kelamin

Responden

\begin{tabular}{lcc}
\hline Jenis Kelamin & $\mathrm{f}$ & $\%$ \\
\hline Laki - laki & 19 & 33.3 \\
Perempuan & 38 & 66.7 \\
Total & $\mathbf{5 7}$ & $\mathbf{1 0 0 . 0}$ \\
\hline
\end{tabular}

Tabel 3. Distribusi Lokasi Pemasangan Infus

\begin{tabular}{lcc}
\hline Lokasi Pemasangan Infus & f & $\%$ \\
\hline Dekat dari persendian & 23 & 40.4 \\
Jauh dari persendian & 34 & 59.6 \\
Total & $\mathbf{5 7}$ & $\mathbf{1 0 0 . 0}$
\end{tabular}

Tabel 4. Distribusi Jenis Balutan Infus

\begin{tabular}{lcc}
\hline Jenis Balutan Infus & $\mathrm{f}$ & $\%$ \\
\hline Balutan Kassa & 49 & 86.0 \\
Balutan Trasnparan & 8 & 14.0 \\
Total & $\mathbf{5 7}$ & $\mathbf{1 0 0 . 0}$ \\
\hline
\end{tabular}

\begin{tabular}{lcc}
\multicolumn{3}{c}{ Tabel 8. Distribusi Kejadian Phlebitis } \\
\hline Kejadian Phlebitis & $\mathrm{f}$ & $\%$ \\
\hline Tidak terjadi Phlebitis & 32 & 56.1 \\
Terjadi Phlebitis & 25 & 43.9 \\
Total & $\mathbf{5 7}$ & $\mathbf{1 0 0 . 0}$ \\
\hline
\end{tabular}




\section{Analisa Bivariat}

Tabel 9. Analisa Bivariat Faktor- faktor Yang Mempengaruhi Phlebitis

\begin{tabular}{|c|c|c|c|c|}
\hline Variabel & Tidak Terjadi & Terjadi & p-value & $\mathrm{r}$ \\
\hline \multicolumn{5}{|l|}{ Usia: } \\
\hline 20- 40 tahun & $100 \%$ & $0 \%$ & 0,016 & 0,317 \\
\hline $41-65$ tahun & $50 \%$ & $50 \%$ & & \\
\hline$>65$ tahun & $42,9 \%$ & $57,1 \%$ & & \\
\hline \multicolumn{5}{|l|}{ Jenis Kelamin: } \\
\hline Laki- laki & $68,4 \%$ & $31,6 \%$ & 0,193 & 0.175 \\
\hline Perempuan & $50 \%$ & $50 \%$ & & \\
\hline \multicolumn{5}{|l|}{ Lokasi pemasangan infus: } \\
\hline Dekat dari persendian & $34,8 \%$ & $65,2 \%$ & 0,007 & 0,354 \\
\hline Jauh dari persendian & $70,6 \%$ & $29,4 \%$ & & \\
\hline \multicolumn{5}{|l|}{ Hubungan jenis balutan infus: } \\
\hline Balutan Kassa & $55,1 \%$ & $44,9 \%$ & 0,702 & 0,052 \\
\hline Balutan Transparan & $62,5 \%$ & $37,5 \%$ & & \\
\hline \multicolumn{5}{|l|}{ Penyakit penyerta: } \\
\hline Masalah penyakit pembuluh darah dan & $41,9 \%$ & $58,1 \%$ & & \\
\hline komponen darah & & & 0,018 & 0,313 \\
\hline $\begin{array}{l}\text { Tidak berhubungan masalah penyakit } \\
\text { pembuluh darah dan komponen darah }\end{array}$ & $73,1 \%$ & $26,9 \%$ & & \\
\hline \multicolumn{5}{|l|}{ Jenis cairan infus: } \\
\hline Isotonis & $64,1 \%$ & $35,9 \%$ & & \\
\hline Hipotonis & $57,1 \%$ & $42,9 \%$ & 0,049 & 0,262 \\
\hline Hipertonis & $27,3 \%$ & $72,7 \%$ & & \\
\hline \multicolumn{5}{|l|}{ Lama terpasang infus: } \\
\hline$<3$ hari & $64,4 \%$ & $35,6 \%$ & 0,014 & 0,324 \\
\hline$>3$ hari & $25 \%$ & $75 \%$ & & \\
\hline
\end{tabular}




\section{PEMBAHASAN}

\section{Hubungan Usia terhadap Kejadian Phlebitis}

Berdasarkan hasil analisa pada kategori usia, pada usia lebih dari 65 tahun yang mengalami kejadian phlebitis sebanyak $57,1 \%$, jumlah ini lebih banyak dari pada kategori usia lainnya. Dari hasil analisa menunjukan bahwa P-value 0,016 karena p-value $<0,05$ artinya terdapat hubungan antara usia terhadap kejadian phlebitis.

Hasil penelitian ini sejalan dengan penelitian Fitriyanti, S (2013) yang menyatakan bahwa usia responden yang lebih dari 45 tahun memiliki kejadian phlebitis $30,9 \%$, sedangkan usia responden yang kurang dari 45 tahun memiliki kejadian phlebitis $1,5 \%$.

Berdasarkan pengamatan di rumah sakit pasien yang berusia $>60$ tahun saat melakukan pemasangan infus mengalami kesulitan seperti pembuluh darah yang rapuh sehingga saat pemasangan kateter vena mudah pecah dan pembuluh darah mudah bergeser saat pemasangan (elastisitas vena berkurang).

Hal tersebut karena penambahan usia mengakibatkan berbagai perubahan fungsi tubuh baik secara fisik, biologis, psikologis dan sosial. Salah satu perubahan fisik tersebut adalah penurunan sistem imun tubuh. Sistem imunitas tubuh memiliki fungsi yaitu membantu mencegah infeksi yang disebabkan oleh jamur, bakteri, virus dan orgaanisme lain serta menghasilkan antibodi (sejenis protein yang disebut immunoglobulin) untuk memerangi serangan bakteri dan virus asing ke dalam tubuh fungsi sistem imunitas tubuh (immunocompetence) menurun sesuai umur, hal ini bukan berarti manusia lebih sering terserang penyakit, tetapi saat menginjak usia tua maka resiko kesakitan meningkat seperti penyakit infeksi, kanker, kelainan autoimun, atau penyakit kronik (Fatmah, 2006).

\section{Hubungan Jenis Kelamin terhadap Kejadian Phlebitis}

Berdasarkan hasil analisa menunjukan bahwa P-value 0,193 karena p-value > 0,05 artinya tidak terdapat hubungan antara jenis kelamin terhadap kejadian phlebitis. Kejadian phlebitis dapat terjadi pada jenis kelamin perempuan atau lakilaki.

Hasil penelitian ini sejalan dengan hasil penelitian menurut Fitriyanti, $\mathrm{S}$ (2013) dimana responden dengan jenis kelamin wanita memiliki kejadian phlebitis 20,6\% sedangkan pada laki- laki 11,8\%. Menurut penelitian Soraya, R (2014) responden berjenis kelamin perempuan sebanyak 71,9\% lebih banyak mengalami phlebitis dibandingkan dengan jenis kelamin laki- laki sebanyak 28,1\%.

Peneliti berpendapat terdapat faktor lain yang lebih mempengaruhi timbulnnya 
phlebitis, karena jenis kelamin hanya merupakan faktor resiko yang dapat meningkatkan terjadinya phlebitis, dan merupakan faktor utama pencetus timbulnya phlebitis. Adapun beberapa faktor yang bisa menyebabkan phlebitis seperti berasal dari jenis cairan, usia, perawatan kateter infus, balutan, rotasi pemasangan, lama dirawat dan aktivitas dari pasien (Potter \& Perry, 2005).

\section{Hubungan Lokasi Pemasangan Infus terhadap Kejadian Phlebitis}

Berdasarkan hasil analisa menunjukan bahwa $P$-value 0,007 karena p-value < 0,05 artinya terdapat hubungan antara lokasi pemasangan infus terhadap kejadian phlebitis. Dimana semakin jauh letak pemasangan infus dari persendian maka semakin kecil kemungkinannya terkena phlebitis.

Penelitian ini sejalan dengan penelitian Asrin (2006) bahwa tempat penusukan sebagai salah satu faktor penyebab phlebitis dengan angka kejadian phlebitis di vena fossa cubiti sebanyak $56 \%$ dan vena kaki sebanyak 12\%. Dari hasil penelitian Samuel, K (2014) bahwa terjadinya phlebitis sebagian besar terjadi yang terpasang pada area pergelangan tangan sebanyak $66,7 \%$, pada area tangan sebanyak $50,77 \%$ dan area lengan bawah sebanyak $42,5 \%$.
Tempat pemasangan infus pada daerah yang sering digunakan untuk beraktivitas klien dapat meningkatkan kejadian plebitis, hal ini sesuai dengan yang dikatakan Hanskins dkk (2001) bahwa penempatan kateter pada daerah yang bergerak misalnya siku atau pergelangan tangan akan menyebabkan resiko terjadinya plebitis lebih banyak, dibandingkan dengan yang memiliki pergerakan minimal, karena ketika pasien bergerak dapat memicu pergerakan kanul atau kateter sehingga melukai dinding pembuluh darah, dan sebaiknya pada saat melakukan penusukan lebih baik dilakukan mulai dari vena yang lebih distal, apabila penusukan tidak berhasil maka bisa di teruskan ke vena yang medial atau proksimal.

\section{Hubungan Jenis Balutan Infus terhadap Kejadian Phlebitis}

Berdasarkan hasil analisa menunjukan bahwa P-value 0,702 karena p-value > 0,05 artinya tidak terdapat hubungan antara jenis balutan infus terhadap kejadian phlebitis.

Penelitian ini sejalan dengan penelitian dari Soraya, R (2014) bahwa balutan transparan dan kassa pada uji mann whitney menunjukkan $\mathrm{p}=0,87(\mathrm{p}>0,05)$ artinya tidak ada perbedaan yang bermakna antara balutan transparan dan balutan kassa terhadap kejadian phlebitis. 
Pada penelitian menurut Rahayu, B (2009) dari hasil uji statistik $\mathrm{p}=0,277(\mathrm{p}>0,05)$ artinya tidak ada perbedaan kejadian phlebitis antara penutupan daerah insersi dengan kassa bethadin steril dengan currapor iv dressing. Sedangkan penelitian menurut Samuel, K (2014) dari hasil perhitungan statistik menunjukkan $\mathrm{p}=$ 0,31 ( $\mathrm{p}>0,05$ ) tidak ada hubungan yang bermakna antara penggunaan balutan leukoplast, dynaplast dan paper tape terhadap kejadian phlebitis.

Hasil penelitian ini menunjukan bahwa jenis balutan tidak terlalu signifikan dalam mempengaruhi timbulnya phlebitis, peneliti berpendapat bahwa apapun jenis balutan yang digunakan baik itu balutan transparan maupun balutan kasa, dapat digunakan dan bisa mencegah phlebitis sepanjang sterilisasi dapat dipertahankan (Aprilin, 2011). Tidak hanya itu saja, penyebab terjadinya phlebitis pada pasien sebenarnya tidak hanya di karenakan oleh dressing saja namun bisa juga berasal dari tingkat usia, cairan, penyakit penyerta, status gizi, stress, jenis kelamin, kepatuhan klien dan sebagainya (Gayatri \& Handayani, 2006).

\section{Hubungan Penyakit Penyerta terhadap Kejadian Phlebitis}

Berdasarkan hasil analisa menunjukan bahwa $P$-value 0,018 karena p-value < 0,05 artinya terdapat hubungan antara penyakit penyerta terhadap kejadian phlebitis.

Berdasarkan hasil penelitian didapatkan data bahwa sebagian besar responden penelitian yang dirawat di ruang Anggrek memiliki penyakit penyerta yaitu sebanyak $58,1 \%$. Penyakit penyerta yang diderita oleh pasien dalam penelitian ini adalah penyakit pembuluh darah dan komponden darah. Hal ini pun yang merupakan salah satu faktor yang menyebabkan timbulnya phlebitis.

Hasil ini sejalan dengan penelitian Fitriyanti, S (2013) kejadian phlebitis pada klien dengan ada penyakit penyerta memiliki 29,4\% lebih besar dibandingkan dengan klien yang tidak ada penyakit penyerta yaitu $2,9 \%$. Didukung pula oleh penelitian Chandra (2013) yang menyebutkan bahwa responden yang sering mengalami phlebitis memiliki penyakit penyerta (Hipertensi, Ginjal, DM, Sepsis, CHF) yaitu sebanyak $40 \%$.

Faktor pasien yang dapat mempengaruhi angka phlebitis mencakup usia, jenis kelamin dan kondisi dasar (diabetes mellitus, infeksi, luka bakar). Pada pasien Diabetes Melitus yang mengalami aterosklerosis akan mengakibatkan aliran darah ke perifer berkurang sehingga jika terdapat luka mudah mengalami infeksi (Darmawan, 2008). 
Penyakit penyerta gagal ginjal kronik juga merupakan salah satu penyebab terjadinya phlebitis, dimana phlebitis pada gagal ginjal kronik ini dikaitkan pada posisi pemasangan infus. Pemasangan infus pada daerah lengan bawah pada pasien gagal ginjal memiliki resiko lebih besar untuk menyebabkan phlebitis karena lokasi tersebut yang sering digunakan untuk pemasangan fistula arteri-vena $(A-V$ Shunt) pada tindakan hemodialisa (cuci darah) (Darmadi, 2008).

\section{Hubungan Jenis Cairan Infus terhadap Kejadian Phlebitis}

Berdasarkan hasil analisa menunjukan bahwa P-value 0,049 karena p-value < 0,05 artinya terdapat hubungan antara jenis cairan infus dengan kejadian phlebitis.

Hasil penelitian ini sejalan dengan penelitian Gayatri \& Handiyani (2007) pada 3 Rumah Sakit di Jakarta bahwa responden yang hanya mendapatkan 1 jenis cairan dengan osmolalitas dan $\mathrm{PH}$ sama dengan cairan tubuh diperoleh probabilitas untuk tidak mendapat phlebitis pada $3 \times 24$ jam adalah $72 \%$. Pada kelompok yang mendapatkan 2 cairan dengan osmolalitas dan PH normal didapatkan probabilitasnya pada 3 x 24 jam menjadi 54\%. Pada kelompok yang mendapat cairan dengan osmolalitas yang lebih tinggi atau $\mathrm{PH}$ yang lebih tinggi probabilitasnya pada 3 × 24 jam menjadi
29\%. Hal tersebut menentukan adanya perbedaan signifikan antara jenis cairan yang diberikan untuk tidak terjadinya phlebitis.

Menurut Pujasari dalam bukunya Darmawan (2008) faktor-faktor yang mempengaruhi terjadinya plebitis adalah jenis cairan, jenis obat, tempat insersi, ukuran kateter, fiksasi yang kurang adekuat, Sedangkan faktor risiko terjadinya plebitis adalah umur, jenis kelamin, kecepatan tetesan cairan infus dan letak vena. Adanya hubungan tersebut disebabkan karena cairan dengan osmolalitas tinggi sangat rentan untuk terjadi plebitis karena dalam teori bahwa cairan ini dengan mudah dapat menyebabkan sel mengkerut dan cairan ini menarik air dari kompartemen intraseluler ke kompartemen ekstraseluler.

\section{Hubungan Lama Terpasang Infus terhadap Kejadian Phlebitis}

Dari hasil analisa menunjukkan bahwa $P$-value 0,014 karena $\mathrm{p}$-value $<0,05$ artinya terdapat hubungan antara lama terpasang infus terhadap kejadian phlebitis

Hasil penelitian ini sesuai dengan hasil studi observasi Karadag dan Gorgulu (2000) didapatkan rata-rata plebitis tertinggi terdapat pada pasien yang menggunakan kateter IV setelah hari ke-4 $(51,4 \%)$. Sedangkan $34,5 \%$ pemakaian $1-3$ hari. Didukung pula oleh penelitian yang 
dilakukan oleh Imram (2016) yang menunjukan bahwa ada pengaruh lama pemasangan infus terhadap kejadian plebitis, pada pasien rawat inap di bangsal penyakit dalam dan syaraf Rumah Sakit Nur Hidayah Bantul sebanyak 56\% yang terpasang infus lebih dari 3 hari dan sebanyak $44 \%$ yang terpasang infus kurang dari 3 hari.

Berdasarkan hasil pengamatan selama di rumah sakit pasien yang terpasang infus lebih dari 3 hari sering mengalami phlebitis, alasan perawat tidak mengganti kateter vena selama $3 \times 24$ jam sudah dilakukan edukasi resiko pemasangan infus yang terpasang lama dapat menyebabkan terjadinya infeksi sampai dengan demam dan menambah keluhan dan penyakit baru bagi pasien, tetapi pasien tidak mau diganti dengan alasan saat ini infus masih terpasang bagus dan tidak ada keluhan seperti bengkak atau nyeri.

Hal tersebut sejalan dengan hasil penelitian dari Pusat penelitian di Amerika (CDC) yang merekomendasikan penggantian dan pindah tempat insersi dilakukan 48-72 jam pada pasien dewasa (Pearson, 1996). Banyak faktor yang menyebabkan flebitis antara lain : teknik cuci tangan yang tidak baik saat pemasangan atau pun perawatan infus, teknik aseptic yang kurang baik pada saat penusukan, teknik penusukan yang kurang tepat, pemasangan yang terlalu lama dan jenis terapi atau cairan yang masuk melalui kateter infus (Makary, 2006).

\section{SIMPULAN}

Penelitian menunjukan terdapat hubungan antara usia terhadap kejadian phlebitis ( $p$-value 0,016), tidak terdapat hubungan antara jenis kelamin terhadap kejadian phlebitis ( $\mathrm{p}$-value 0,193), terdapat hubungan antara lokasi pemasangan infus terhadap kejadian phlebitis (p-value 0,007), tidak terdapat hubungan antara jenis balutan infus terhadap kejadian phlebitis (p-value 0,702), terdapat hubungan antara penyakit penyerta terhadap kejadian phlebitis (p-value 0,018), terdapat hubungan antara jenis cairan infus terhadap kejadian phlebitis (pvalue 0,049), terdapat hubungan antara lama terpasang infus terhadap kejadian phlebitis (p-value 0,014).

\section{SARAN}

Melakukan sosialisasi kepada seluruh perawat dalam melakukan penilaian Visual Infusion Phlebitis Score (VIP) sehingga mampu menentukan intervensi yang dilakukan untuk mencegah plebitis di rumah sakit. Untuk penelitian selanjutnya dapat mencari faktor lain yang menyebabkan plebitis dan melakukan komparasi standar penilaian plebitis dari Kemenkesh dan Joint Commission 
International (JCI) yang lebih mudah efektif digunakan oleh perawat dalam mencegah kejadian plebitis.

\section{DAFTAR PUSTAKA}

Arsin, dkk. (2006). Analisis Faktor-faktor Yang Mempengaruhi Terhadap Kejadian Phlebitis di RSUD Purbalingga. (online). http://jos.unsoed.ac.id/index.php/ke perawatan/article/view/241.

Diakses tanggal 30 Juli 2016. Jam 20.00 .

Darmadi, S. (2008). Infeksi Nosokomial Problematika \& Pengendaliannya. Jakarta: Salemba Medika.

Darmawan, I. (2008). Flebitis, Apa Penyebabnya dan Bagaimana Cara Mengatasinya. Edisi 2. Jakarta: Yayasan Bina Pustaka.

Depkes RI. (2006). Standar Pelayanan Minimal Rumah Sakit. Jakarta: Direktorat Jenderal Pelayanan Rumah Sakit Umum.

Fatmah. (2006). Respon Imunitas yang Rendah Pada Tubuh Manusia Usia Lanjut. Makara Kesehatan 10 (1): 47- 53.

Fitriyanti, S. (2013). Faktor- faktor Yang Mempengaruhi Terjadinya Phlebitis di Rumah Sakit Bhayangkara TK. II. H. S. Samsoeri Mertojoso. (online). http://obstetri-ginekologifk.unair.ac.id/index.php/jbe/article/v iew/1663. Diakses tanggal 20 Mei 2016. Jam 20.35.

Gayatri, D., Handiyani, H. (2007). Hubungan Jarak Pemasangan Terapi Intravena Dari Persendian Terhadap Waktu Terjadinya Phlebitis. (online). http://jki.ui.ac.id/index.php/jki/articl e/view/178. Di akses tanggal 28 Juli 2016. Jam 00.15.

INS. (2008). Setting the standard for infusion care. (online). http://www.ins1.org. Diakses tanggal 25 Juli 2016. Jam 22.10.

Kozier, B, et al. (2010). Buku Ajar Keperawatan: Konsep, Proses dan Praktik. Edisi 7 Vol 2; Alih Bahasa, Karyuni, P. E, et al; Editor Bahasa Indonesia, Widiarti, D. Jakarta: EGC.

Potter \& Perry. (2005). Buku Ajar Fundamental Keperawatan Konsep, Proses, dan Praktek Edisi 7 Buku 3; Alih Bahasa, Diah, F. N, et al. Jakarta: Salemba Medika.

Rohani., Setio, H. (2010). Panduan Praktik Keperawatan Nosokomial. Yogyakarta: Citra Aji Parama.

Soraya, R, dkk. (2014). Perbedaan Efektifitas Antara balutan Transparan Dan Balutan Kassa Terhadap Kejadian Phlebitis di RSUD Kota Salatiga. (online) 